\title{
Playing Antarctica: Making music with natural objects and sounds from the Antarctic Peninsula
}

\author{
Cheryl E Leonard ${ }^{1}$
}

\section{The project}

In 2008 I was awarded a grant from the Antarctic Artists and Writers Program of the United States National Science Foundation to develop a series of musical compositions inspired by environments and ecosystems on the Antarctic Peninsula. This grant enabled me to spend five weeks at Palmer Research Station during the austral summer of 2008-09 collecting materials for my project Antarctica: Music From the Ice.

The project is a set of ten musical works in which Antarctic field recordings are combined with sounds produced on natural-object instruments, primarily materials from the Antarctic Peninsula. Each piece is based on an aspect of the environment near Palmer Station and connects to scientific research underway in the region. Compositions are scored out and performed live on stage by a small ensemble. The completed works are being recorded and will be released digitally and on CD in 2015.

Antarctica: Music From the Ice grows out of my extensive previous experience creating compositions, improvisations, and instruments that investigate sounds, structures, and objects from the natural world. Over the past decade I have developed many works based on subjects such as cloud formations, estuary ecosystems, geological formations, and the properties of water. Since 2003 I have been composing with sounds from found natural materials, often building sculptural instruments from pinecones, bark, driftwood, shells, bones, feathers, and more. By amplifying such materials with contact, condenser, and underwater microphones, very quiet sounds hidden within them are revealed and voices of surprising character and intricacy emerge.

A passion for wild and remote places drives my creative process and I have a particular fondness for glaciers and alpine environments. Shrouded in ice, largely untouched, and inaccessible to most people, Antarctica was the ultimate

1 Ms Cheryl Leonard, 2352 Fulton St, San Francisco, CA 94118, USA, cheryleleonard@gmail.com. 
subject for me, and the opportunity to make music in and about the frozen continent was endlessly exciting. I was especially curious about unique wind, wildlife, water, and ice sounds I might encounter there, and was eager to see what new voices I might coax out of Antarctic rocks, shells, bones, and ice.

\section{At Palmer Station}

Palmer Research Station is located on Anvers Island off the Antarctic Peninsula at $64^{\circ} 46^{\prime} \mathrm{S}, 64^{\circ} 03^{\prime} \mathrm{W}$. It is the smallest of the three permanent research stations operated by the United States in Antarctica, with a summer population of around 40 people. There is no airstrip at Palmer, so to reach the station one must travel by boat from the tip of South America across the Drake Passage. I sailed south from Punta Arenas, Chile, on the Lawrence M Gould, a $76 \mathrm{~m}$ long US research vessel, which can carry up to 26 researchers and 15 crew members. The Gould's maximum speed is around 11 knots, and the ship usually takes about four days to sail from Punta Arenas to Palmer Station.

Upon our arrival at Palmer the other visiting artist, Oona Stern, and I were schooled in station procedures, Antarctic survival, ocean rescue, and the safe operation of 'zodiacs' - the small but hardy inflatable boats used for local transport. After a few days of supervised boating we were assigned our own zodiac, dubbed the Artboat 66, and were free to roam within the safe boating area, which extends in a two-mile radius around the station. Although this might sound like a very limited range, we experienced no shortage of fascinating destinations. Many small islands are located within the boating limits, each with its own unique character, landforms, wildlife populations, and sounds. Several calving edges of the Marr Ice Piedmont, the massive glacier that blankets most of Anvers Island, were also within bounds, and an endless stream of icebergs and brash ice floated through the area.

Each day at Palmer, Oona and I set out from the station and explored our surroundings. If the weather was fair and winds were below 20 knots, we hopped in the Artboat 66 and motored out to neighbouring islands or worked on the sea out of our zodiac. In stormy conditions, when boating was out of the question, I wandered around the 'backyard' behind the station, scrambling over rocky glacial moraine and up onto a little crevasse-free toe of the glacier.

One of the things that surprised me most about the Antarctic Peninsula was what a noisy and vibrant place it could be. In contrast to the usual rendering of Antarctica as a barren, white, quiet (except for the wind) land, during my visit Palmer Station's environs teemed with life, sound, and even patches of vivid colour. Krill swarmed in the sea, all the birds were nesting, seals floated by on 
bergy bits, and humpback whales regularly cruised through our local waters. Bright green mosses flourished in protected nooks, and splashes of brilliant yellow and orange lichen adorned rocky outcrops.

The kazooing of distant penguin colonies mixed with explosive snorts and howls from elephant seals, barking fur seals, squawking skuas, and squeaky terns. Meanwhile, the Marr Ice Piedmont punctuated the soundscape with great booms and gunshots as it calved immense towers of ice into the sea. The remains of these demolitions disintegrated into snapping, popping icebergs and great swathes of clinking brash ice that were regularly washed out into the open ocean. Beneath the glacier's dissolving walls water drips played gamelan-like melodies, and on the surface of the Marr small meltwater streams gurgled in cyclical rhythms or moaned and sang. Finally, framing all these busy sonorities were the ever present, ever changing intonations of wind and waves.

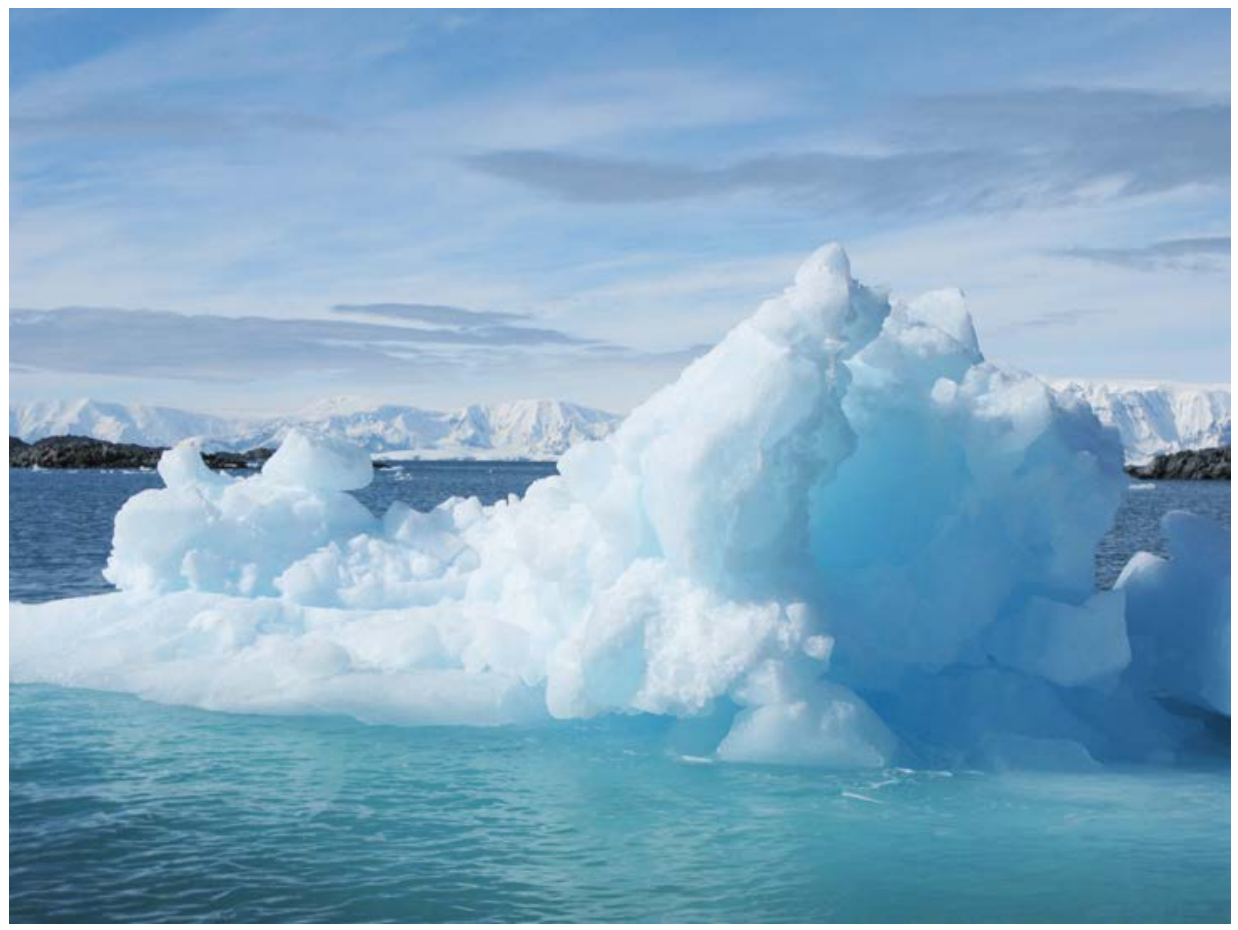

Figure 1. Small iceberg near Shortcut Island. The mountains in the distance are on the mainland peninsula about $\mathbf{3 0}$ kilometres away.

Source: Photo by Cheryl E Leonard. 


\section{Field recordings}

During my forays through these rich environs I collected many hours of field recordings, some captured in the air, and some underwater via a pair of hydrophones.

I was immediately drawn to the melodious footsteps of the adelie penguins on Torgersen Island, and these sounds never ceased to delight me. Torgersen, on which thousands of pairs of adelies raise their young each year, is covered in shards of a dense, sonorous, igneous rock. As the penguins ambled along wellworn paths between colonies and beaches, the stone fragments clinked under their feet, producing delicate music. It was great fun to set my microphones up along the edge of a walkway and record lines of birds jingle-jangling by.

The southern elephant seals were another one of my favourite recording subjects. I first heard them during an early zodiac outing to a cove on Amsler Island. As we turned off the outboard motor and slowly drifted across the water, deep alien bellows emerged from the far end of the cove, echoing off the 30-foot tall walls of ice on either side of us. There in the water a couple of dark shapes tumbled and splashed. Several more massive creatures lay side-by-side on the shore. I quickly pulled out my pocket recorder, but after a few short minutes the seals' outlandish calls ended abruptly.

Thus began my quest to record elephant seal vocalisations. I returned to Amsler Island numerous times hoping to find them howling in the cove's sheltered waters, but instead they were always piled up on the shore, fast asleep. I made several fine recordings of snoring, snoozing seals, but still I longed to capture their haunting roars.

Finally, I decided to camp out on the island for a night. I waited for a window of fair weather and then, one balmy evening, was dropped off on Amsler a few hours before sunset. Shortly after the departing zodiac's motor faded into the distance, I heard it, the faint bawls and bellows, splashes and sputters, of southern elephant seals in the water. This time there weren't just a couple of them cavorting, there were over a dozen, sparring in pairs in the shallow cove. I don't know why it hadn't occurred to me before that the elephant seals might be nocturnal! Suddenly it was painfully obvious why they were conked out on the beach all day. In the long Antarctic dusk the seals' playful martial dances and eerie roars were mesmerizing. I watched, listened, and recorded until, in the wee hours of the night, I could no longer feel my toes.

Perhaps the most surprising animal vocalisation I heard at Palmer was the noise an Antarctic fur seal made when I happened upon it at close range. Although they look like adorable sea puppies, fur seals are creatures to be wary of. They 
can run faster than a human on land and have been known to bite people when they feel threatened. Thus, when I unexpectedly ran into one napping on a grassy hummock in the middle of Amsler Island it was with heightened alertness that I pulled out my microphones. The seal looked up, I got ready to run, and then it produced a kind of nervous whimpering which was not at all what I was expecting from a creature that might chase me down and chomp on me.

I also spent a lot of time recording ice: drifting brash, bergy bits and icebergs, and the disintegrating edges of the glacier. Out on the sea, I lowered my hydrophones over the sides of the zodiac to record the ice underwater at different depths, or tempted fate by leaning out over the water with a pair of expensive condenser microphones in my hand. The floating ice emitted an astonishing array of sounds. Smaller fragments clinked and thunked against each other, sometimes chaotically, sometimes in repeating rhythms. Waves thumped and boomed in hollows carved into larger pieces. Areas of pureed ice sloshed against the zodiac's rubber sides, giving the impression that we were floating in a giant slushie. Often the melting ice snapped and popped, as air that had been trapped inside the glacial ice for who-knows-how-long was released.

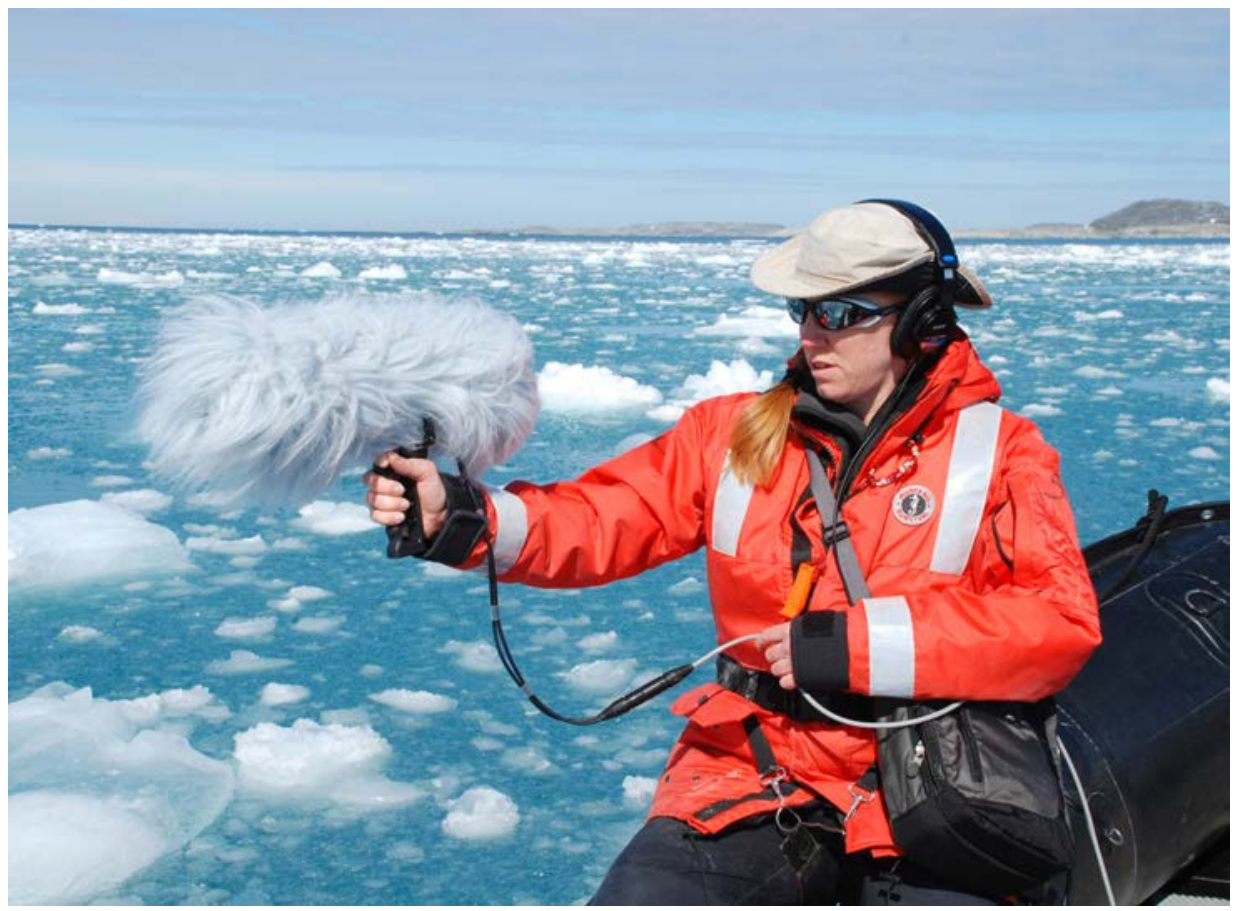

Figure 2. Recording brash ice from the zodiac.

Source: Photo by Oona Stern. 
On land I staked out the Marr Ice Piedmont in order to capture the thunderous booms and cracks it produced as great chunks of ice calved off its waterfront edges into the sea. I also recorded small meltwater streams on the glacier's periphery and had the opportunity to descend inside two crevasses farther up on the Marr.

From the surface of the glacier the crevasses didn't look like much, just ominous cracks in the snow, but inside lay ornate azure caverns adorned with thousands of icicles. Because it was summer and temperatures were above freezing, hanging on a rope inside a crevasse was a lot like taking a shower. First, I recorded just the multitude of water drops, and then I began to play some nearby icicles, cautiously tapping them with a pair of superball mallets. Lovely clear pitches emerged. Unfortunately, often the icicles fractured just as I started to get nice resonant tones from them and they fell shattering in the icy depths beneath me. Although I knew they would grow back in a few days it was a little upsetting to be destroying the icicles. On the other hand, they produced a magnificent madxylophonist cacophony as they fell, bouncing and echoing for a surprisingly long time.

\section{Collecting natural objects}

In addition to making field recordings while onsite at Palmer Station, with special permission I also gathered limpet shells, penguin bones, and rocks to bring back to the United States and use as musical instruments.

On my inaugural excursion into Palmer's rubbly 'backyard' I came across a few scattered limpet shells. Delighted, and grinning like a small child on a treasure hunt, I greedily gathered up all the shells I could find - about five or six of them. They clinked pleasingly as I turned them over in my palms and wobbled them on a flat granite slab. Excitedly, I returned to the station to show off my find, but was disappointed when none of the veteran Palmerites seemed very impressed. This puzzled me, because I had walked all over the moraine behind the station and had only been able to find a few shells.

Shortly thereafter I visited DeLaca Island. As soon as I scrambled up onto the island's stony ramparts I understood - here were limpet shells heaped up by the thousands. As it turns out, Antarctic limpets (Nacella concinna) are very common in the Antarctic Peninsula and are an important food source for gulls and sea stars. The giant piles of limpet shells on DeLaca were the remains of many, many kelp gull meals. The gulls swallow the limpets whole and then regurgitate the shells. Interestingly, if they are not eaten sooner, Nacella concinna can live to be over 100 years old, so it's likely that many of the shells I collected are older than I am. 
From two other islands near the station, Torgersen and Breaker, I gathered stones. Breaker Island is formed from an igneous rock that tends to break into thin plates. Tapping my way around Breaker's craggy edifices I found that many of them emitted ringing, pitched tones. I assembled a set of eight small slabs, which together form a pleasing scale, to bring home.

From Torgersen Island, home to many adelie penguin rookeries, I selected a handful of the stones these birds use to build their nests. Adelies have raised chicks on Torgersen for hundreds of years and, over that time, their nesting stones have become highly polished from use. I chose stones from an abandoned nesting site, where a now-extinct colony once thrived. The little glossy rock shards chime like pieces of glass.

Strewn among the rocks of many islands I often found small, sun-bleached bones, usually the remains of adelie penguins. In areas where adelies nest, bones are readily found on the outskirts of colonies. Skuas linger there, always on the lookout for weak chicks or injured adults to attack and eat. I amassed an assortment of adelie bones — including leg and wing bones, pelvises, breastbones, and two skulls - and was eager to see what sounds I could produce with them.

\section{Developing compositions}

After a little over a month at Palmer Station it was time to board the Gould once again to sail north to Chile, and then take a wearying series of airplanes home to California. Back in my studio in San Francisco I sorted through my field recordings, looking for sounds and ambiences that could form the foundation of compositions, either relatively unchanged, or edited more extensively into musical motives and structures. I also experimented with ways to play the bones, shells, and stones I brought back with me. Searching for distinctive voices, I attached contact mics to these objects or placed them under condenser microphones. I bowed, scraped, tapped, rubbed, brushed, and wobbled until I uncovered voices and textures I liked, sounds that evoked elements of Antarctica.

In order to more easily play the penguin bones and limpet shells, I found I needed to mount them somehow. So I constructed a series of one-of-a-kind instruments using driftwood to hold the bones and shells in place. 


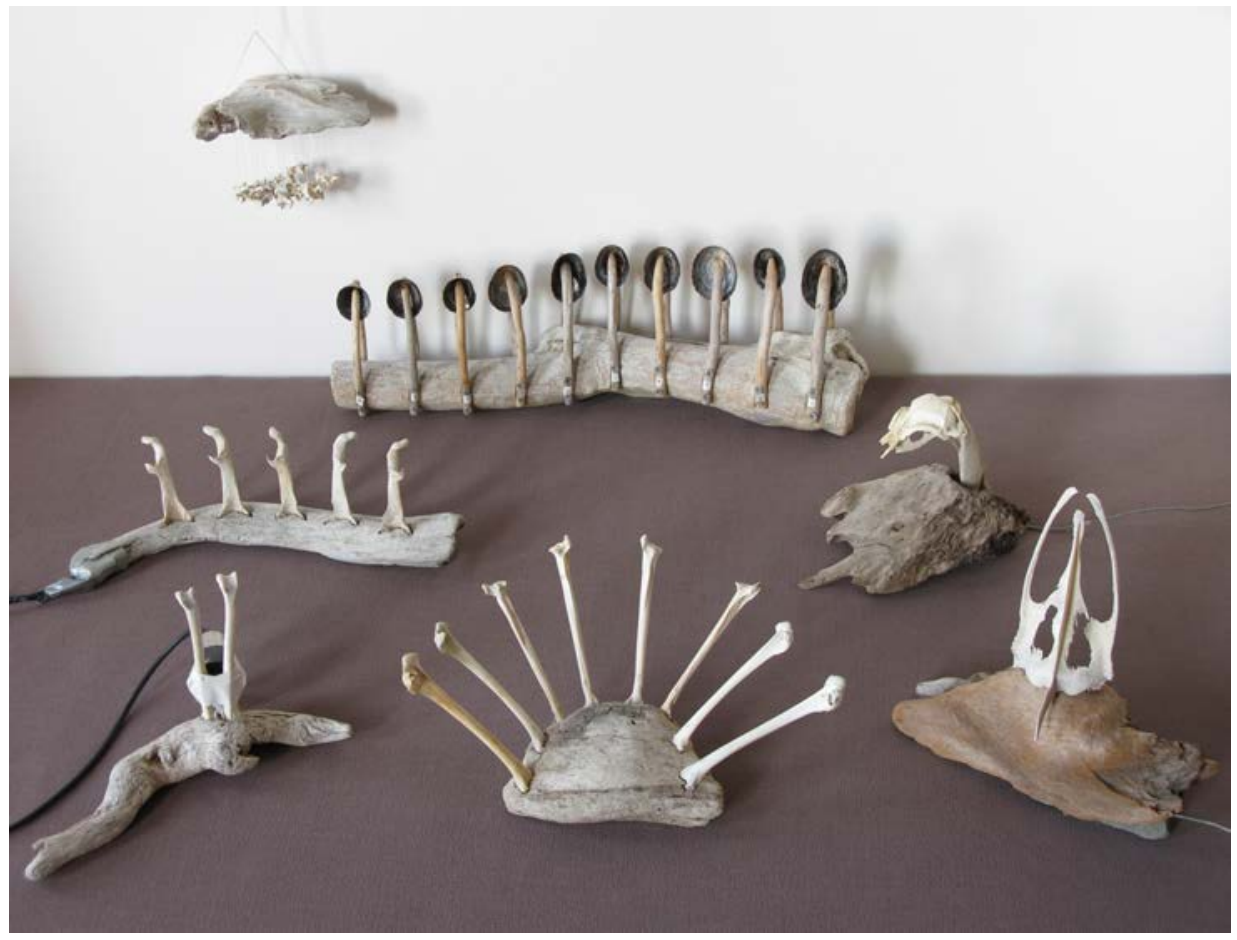

Figure 3. Musical instruments made from penguin bones, limpet shells and driftwood. Left to right: front, 'Bone Slug', 'Octobones', 'Keel'; middle, 'Coracoids', 'Skull'; back, 'Limpet Shell Spine'; hanging, 'Vertebrae Mobile'.

Source: Photo by Cheryl E Leonard.

I selected ten limpet shells that formed a satisfying scale of pitches and mounted them together. This instrument, the 'Limpet Shell Spine,' is played with childsized violin bows, string, pine needles, and feathers. Out of a dozen or so penguin vertebrae and a piece of bone-white driftwood I built a small mobile. Swinging back and forth against each other, the vertebrae sound remarkably like tiny pieces of ice floating in water. The 'Octobones' and 'Coracoids' instruments were created by attaching penguin leg and wing bones to driftwood stands. There is also the 'Keel,' an adelie breastbone mounted upright. My favourite way to play penguin bones is to bow them. By varying bow placement and pressure, the bones produce sounds that range from soft airy breaths to loud pitched howls and warbles.

Melodies can be played on the rock slabs from Breaker Island by stroking them with wire brushes or other stones, or wobbling or dropping rounded pebbles on them. Adelie nesting stones rubbed together sound like high gusts of wind. 
They can also be clinked against each other, another sound reminiscent of brash ice. Of course a wide variety of percussive sounds can also be made with the bones and shells.

After selecting my favourite field recordings and instrumental sounds, I began sculpting them into compositions. My Antarctic works develop from musical elements inherent in the original materials. Aside from amplification, the instruments are not electronically processed in any way, and field recordings are shaped only by editing and layering. Each piece has a unique theme based on an aspect of the Antarctic Peninsula's changing environments and ecosystems, and connected to areas of scientific research in the region. Many of the works relate to recent changes in the climate of the western Antarctic Peninsula: the collapse of local adelie penguin rookeries, morphing weather patterns, and the retreat of local glaciers. The theme of each piece is embodied in its instrumentation, the manner in which objects are played, melodic and rhythmic content, and organisational structures.

\section{Scores and live performances}

Because I compose for unusual sound sources, I have developed my own system of notation in order to articulate how to play each piece. I use a combination of graphics and text instructions, sometimes with sections of traditional music notation mixed in. Each piece requires a unique approach to scoring, depending on the instruments and sounds involved. Time in seconds is listed horizontally across the top of my scores, and the parts for each player, plus any field recording parts, are laid out underneath this timeline.

For 'Point Eight Ice' (see score excerpt below), I invented symbols to represent the different kinds of ice sounds in the field recording part. Vertical lines are pops, shaded-in ovals are rhythmic thunks, checkmarks are knocks, and small zigzags indicate scrapes. 'Octo' and 'Lmpts' are the instrumental parts and refer to sounds played on the 'Octobones' and 'Limpet Shell Spine.' Circled numbers specify which bone or shell to play. Playing techniques are described with text, and graphics indicate the rhythms or shapes of each musical gesture. Numbers in otherwise blank rectangles indicate seconds of rest. 


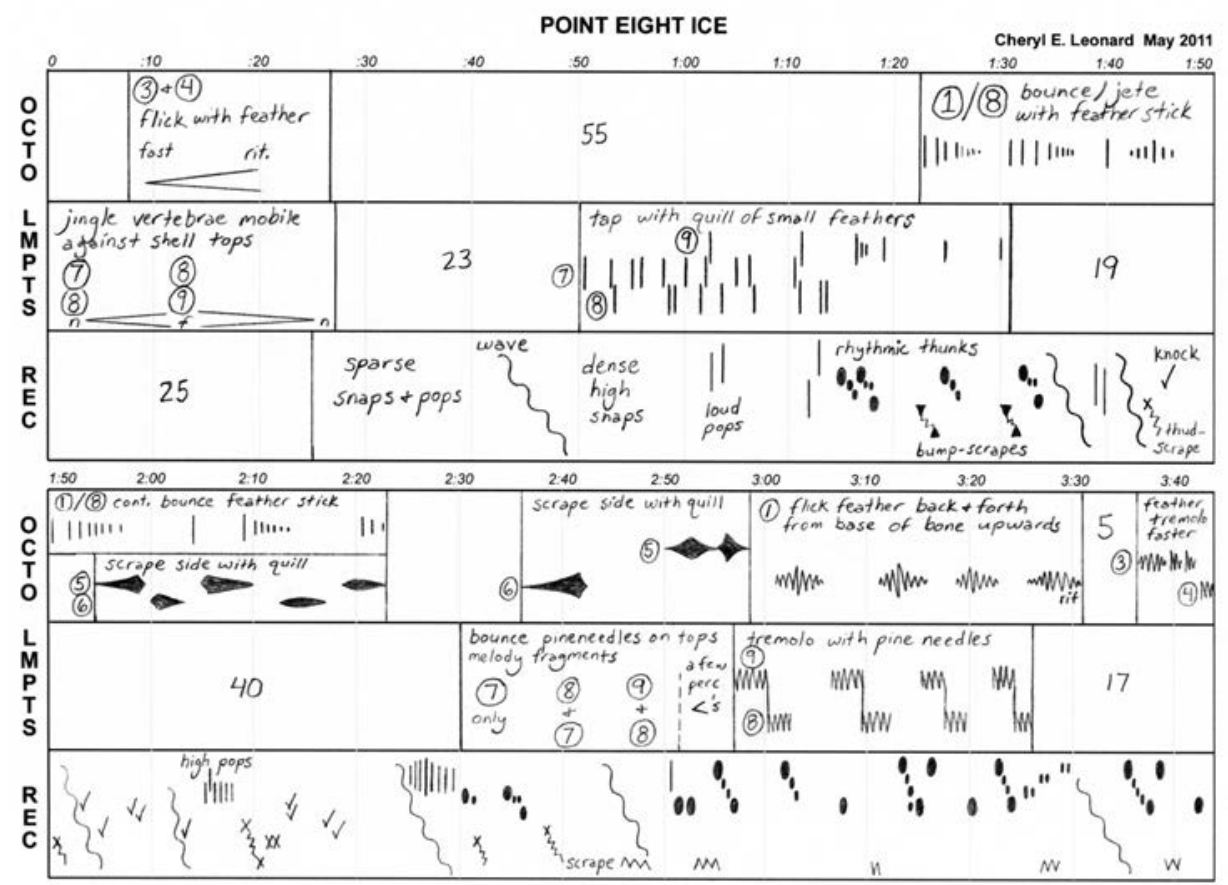

Figure 4. Page 1 of the score for 'Point Eight Ice'.

Source: Author.

I score out my Antarctic compositions so that my ensemble and I can play the pieces live in front of an audience. It is important to me that people are able to experience my Antarctic music live, that they can see the instruments set up on stage and identify how some of the unusual sounds in the music are produced. Live performances also give audiences the opportunity to ask questions, examine the instruments in person, and even try making some sounds on them.

My goal in creating these instruments, musical compositions, and performances is to share a little bit of Antarctica, especially with people who cannot visit the continent themselves. Environments, ecosystems, and the science that investigates them - these elements are important and are embedded in my works. In the end though, my principal hope is that this music helps people feel a meaningful connection to Antarctica, and conveys some of the awe and wonder I experienced during my adventures at Palmer Station. 


\section{Suggested reading and listening}

Ackerman, Diane (1992) The moon by whale light. Vintage Books, New York.

Booth, Joan (2011) The storied ice: exploration, discovery, and adventure in Antarctica's Peninsula region. Regent Press, Berkeley CA.

Dunn, David (1999) Why do whales and children sing? Earth Ear, Santa Fe NM.

Encounters at the End of the World (2007) Dir. Werner Herzog. Discovery Films.

Gosnell, Mariana (2006) Ice: the nature, the history, and the uses of an astonishing substance. Alfred A Knopf, New York.

Hempton, Gordon and John Grossman (2009) One square inch of silence. Free Press, New York.

Hooper, Meredith (2008) The ferocious summer: Adélie penguins and the warming of Antarctica. Greystone Books, Vancouver.

Jarrett, Brett and Hadoram Shirihai (2008) The complete guide to Antarctic wildlife: birds and mammals of the Antarctic Continent and the Southern Ocean, 2nd edn. Princeton University Press, Princeton NJ.

Krause, Bernie (2002) Wild soundscapes. Wilderness Press, Berkeley CA.

Leonard, Cheryl (2009) Chattermarks: Field Recordings from Palmer Station Antarctica CD. Great Hoary Marmot Music, San Francisco CA.

Lopez, Francisco (2005) Wind [Patagonia] CD And/Oar, Seattle WA.

Lopez, Francisco (2007) Lopez Island CD. Elevator Bath, Dallas TX.

McGonigal, David and Lynn Woodworth (2003) Antarctica: the blue continent. Firefly, Buffalo NY.

Montaigne, Fen (2010) Fraser's penguins: a journey to the future in Antarctica. Henry Holt and Co., New York.

Myers, Joan(2006) Wondrous cold: an Antarctic journey. Smithsonian Institution, Washington DC.

Nicklen, Paul (2009) Polar obsession. National Geographic, Washington DC.

Post, Austin and Edward R Lachapelle (2000) Glacier ice. University of Washington Press, Seattle WA. 
Antarctica: Music, sounds and cultural connections

Pyne, Stephen J (1998) The Ice: a journey to Antarctica. University of Washington Press, Seattle WA.

Quin, Douglas (1998) Antarctica CD. Miramar Recordings, Seattle WA.

Rivers and Tides: Andy Goldsworthy Working with Time (2003) Dir. Thomas Riedelsheimer, Roxie Releasing.

Rogers, Susan Fox, ed. (2007) Antarctica: life on the ice. Solas House, Palo Alto CA.

Rothenberg, David and Marta Ulvaeus, eds (2001) The book of nature and music. Wesleyan University Press, Middletown CT.

Schafer, R. Murray (1977) The soundscape. Destiny Books, Rochester VT.

Thomas, David N (2004) Frozen oceans. Firefly Books, Buffalo NY.

Vear, Craig (2005) Antarctica: Musical Images from the Frozen Continent DVD, CD and book. Anthony Craig Vear.

Watson, Chris and BJ Nielsen (2005) Storm CD. Touch Music, London.

Winderen, Jana (2009) Heated CD. Touch Music, London.

Winderen, Jana (2008) 'Drift,' Surface Runoff LP. Touch Music, London. 
This text is taken from Antarctica: Music, sounds and cultural connections, edited by Bernadette Hince, Rupert Summerson and Arnan Wiesel, published 2015 by ANU Press, The Australian National University, Canberra, Australia. 